\title{
Modeling LID using SWMM5 and MIDS Credit Calculator: Credit Valley Conservation's Elm Drive Case Study
}

\author{
Sakshi Saini and Amanjot Singh \\ Credit Valley Conservation Authority, Mississauga, Ontario
}

\begin{abstract}
Low impact development is an innovative stormwater management practice that consists of green infrastructure, source controls, and conveyance controls. Low impact development practices mimic the natural hydrology of a site by increasing the pervious area that allows filtration and infiltration of runoff before draining to a pond, river or creek. The Ontario Ministry of the Environment and Climate Change emphasized the need to control precipitation where it falls by implementing low impact development practices for all forms of development. Pertinent to the widespread application of low impact development practices is proper design, using modeling tools which use or are capable of using local performance data. Taking a step in this direction, Credit Valley Conservation evaluated three models (Minnesota's MIDS Credit Calculator; USEPA's National Stormwater Calculator (SWC); and USEPA's stormwater management model, SWMM) to model a treatment train site, Elm Drive, currently being monitored by Credit Valley Conservation in Mississauga, Ontario. Results from the models were compared to monitored data from the site for the models' performance evaluation. All three models reasonably allowed input of site conditions and LID practices and reproduced results that were comparable with the monitored data. All the models were found suitable for conceptual design stage, whereas SWMM also meets detailed designed needs. An important consideration in applying any of the models is setting them up in accordance with the stormwater management design guidelines. Two imperative guidelines are the catchment impervious area to LID practice area (I/P) ratio and the drawdown time.
\end{abstract}

\section{Introduction and Methodology}

With a push from the Ontario Ministry of Environment and Climate Change (MOECC) and support from the conservation authorities, stormwater practitioners are now integrating low impact development (LID) practices within the traditional stormwater management designs. LID practices are generally used for source, conveyance control of stormwater quality and quantity. However, to quantify how much benefit can be derived from LID practices, practitioners need design tools for assistance. Several stormwater management tools are available in the market which have the capability to model LID practices. The purpose of this paper is to assess three of those models or tools by comparing their output with actual field data from one of Credit Valley Conservation's (CVC) LID monitoring sites.

\subsection{Analysis Methodology}

This case study was undertaken by CVC to evaluate suitability of three existing stormwater management models or tools for modeling LID practices. The three tools/ models are Minnesota's Minimal Impact Design Standards (MIDS) calculator, the USEPA's Stormwater Management Model (SWMM), and the USEPA's National Stormwater Calculator (SWC). The models were assessed for:
- suitability for entering different site conditions and setting up a LID treatment train;

- accuracy of runoff volume reduction and total suspended solids (TSS) and total phosphorus (TP) attenuation; and

- sensitivity to key design parameters.

As a refresher, Table 1 provides key runoff reduction and water quality targets set by regulatory bodies like MOECC and local conservation authorities. However, these targets are currently under review. The new targets and guidelines are expected to be released by the end of 2016 .

Table 1 MOECC and CVC SWM design criteria (MOECC 2003; CVC 2012).

\begin{tabular}{|c|c|}
\hline \multicolumn{2}{|c|}{ Stormwater Management Criteria for New Developments } \\
\hline Flood control (peak flow) & Post- to pre-control of peak flows for the $2 \mathrm{y}$ to $100 \mathrm{y}$ design storms. \\
\hline Erosion control (runoff volume) & At a minimum detain $5 \mathrm{~mm}$. \\
\hline & For sites with stormwater management ponds, detain $25 \mathrm{~mm}$ for \\
\hline Water quality & $\begin{array}{l}48 \mathrm{~h} . \\
\text { Enhanced level of treatment ( } 80 \% \text { TSS removal). }\end{array}$ \\
\hline Water balance & Retain $3 \mathrm{~mm}$ on site. \\
\hline & $\begin{array}{l}\text { Maintain groundwater infiltration to prevent reduction in baseflow } \\
\text { and recharge. }\end{array}$ \\
\hline
\end{tabular}

Saini, Sakshi and Amanjot Singh. 2016. Modeling LID using SWMM5 and MIDS Credit Calculator: CVC's Elm Drive Case Study. Journal of Water Management Modeling 25:C403. doi:10.14796/JWMM.C403 @ CHI 2016. www.chijournal.org ISSN 2292-6062. 


\subsection{Minimal Impact Design Standards (MIDS) Credit Calculator}

The MIDS calculator is a non-continuous, non-hydraulic tool, used to estimate annual stormwater runoff volume reduction and pollutant load reduction for TSS and TP. MIDS also has the capability to simulate dissolved phosphorus (DP) and particulate phosphorus (PP) in runoff. The tool considers a variety of different LID practices. It was developed for the State of Minnesota to assist designers and regulators in determining conformance to the MIDS performance goals, i.e. $1.1 \mathrm{in}$. $(27.94 \mathrm{~mm})$ retention of runoff on site (MPCA 2014).

Different LID practices may be inserted for any one site, and one can manually enter the design details of each practice. Total site area (pervious and impervious) and the area routed to each LID practice is user specified. Site location is based on user entered zip code, and annual precipitation is based on the location. Default pollutant event mean concentration (EMC) values are provided which can be modified based on local data.

Runoff and pollutant loading from one LID practice can be routed to another, making the MIDS Calculator one of the few tools out of its league to be able to model a LID treatment train for quality and quantity.

Calculations are performed in Excel, and a graphical user interface (GUI) is available for data entry and results viewing. Results present runoff volume and pollutant loads generated for the site and amount of runoff and pollutant loading removed by each LID practice as well as the total reduction from the site.

\subsection{USEPA Stormwater Management Model (SWMM)}

The USEPA Storm Water Management Model (SWMM) is a dynamic rainfall-runoff-routing simulation model used for single event or long term (continuous) simulation of runoff quantity and quality. SWMM tracks the quantity and quality of runoff generated within each catchment, and the flow rate, flow depth, and quality of water in each pipe and channel during a simulation period comprising multiple time steps. For this case study, no hydraulic structures (pipes or channels) were modeled.

A site's drainage area is defined through one or many subcatchments with parameters such as soil hydraulic conductivity, slope, percent imperviousness, Manning's coefficient of roughness and depression storage for each catchment. Subcatchments are routed to a single outlet, which can be another subcatchment or a manhole or catchbasin modeled as a node. There is also the option to route between pervious and impervious areas within a subcatchment. This is applicable to real life scenarios when impervious roofs drain to pervious lawns, and do not go directly into the catchbasin with road runoff. Such impervious areas are referred to as non-directly connected impervious areas. Further, nodes are connected by links or conduits which are pipes in the storm water network. Steady flow, kinematic or dynamic wave routing options are available for flow routing in conduits. Surface runoff is calculated using Manning's equation.

The LID control editor allows LID practices to be incorporated into subcatchments. The functionality currently does not allow for routing between LIDs within a subcatchment. Also, removal efficiencies for each LID control cannot be specified in the editor. Multiple LIDs of the same kind can be defined, and may be entered in the same subcatchment.

Precipitation time series can be manually entered, and other climatologic data can also be used, like monthly evaporation averages.

SWMM calculates the runoff, infiltration, evaporation and pollutant loading from each subcatchment and the entire system. Results are presented for the entire duration, and time series results are also produced in tables and graphs.

\subsection{USEPA National Stormwater Calculator (SWC)}

The SWC is a desktop application that estimates the average annual amount of rainwater, and frequency of runoff, from a specific site anywhere in the United States. Similar to MIDS, the primary focus of the SWC is to inform site developers on how well they can meet a desired stormwater retention target with and without the use of LID controls.

SWC uses the SWMM 5 model engine; hence, computations are done the same way as in USEPA SWMM. It was chosen for analysis because it is a simpler version of SWMM designed specifically for the purpose of LID design and performance evaluation, and in the same league as the MIDS calculator.

Location can be specified using an address or a zip code. Total site area input is optional because calculations are based on per unit area. The amount of pervious area versus impervious area is entered as a percentage.

Soil type is represented by its hydrologic soil group. The soil type can be selected based on local knowledge, or by retrieving a soil map overlay in the application from the U.S. Department of Agriculture's Natural Resources Conservation Service (NRCS) SSURGO database. Soil drainage or hydraulic conductivity can be manually input or selected based on the site's soil type.

The precipitation time series file is downloaded based on rain gauge station and weather station closest to the chosen location.

There are seven different types of LID controls available. Any mix of these controls could be applied by simply telling the calculator what percentage of the impervious area is treated by each type of control. Each control has been assigned a reasonable set of design parameters, which can be modified by clicking on the name of the control.

Key differences between SWC and MIDS are first that SWC runs continuous simulation and is sensitive to precipitation distribution over the year, whereas MIDS assumes uniform distribution of annual precipitation; and second that SWC does not provide 
water quality results despite SWMM5 having this capability. MIDS computes water quality results for TSS and TP.

Results presented by the SWC are annual runoff, infiltration, evapotranspiration, percent wet days retained, maximum precipitation retained, smallest rainfall with runoff, largest rainfall with runoff, days per year with rainfall, days per year with runoff, rainfall-runoff exceedance frequency graph, rainfall retention frequency graph, runoff by rainfall percentile graph, and extreme event rainfall-runoff graph. As discussed before, no pollutant input is required, and no water quality computations are conducted, hence no pollutant results are presented by the SWC directly. However, post-processing of the SWMM input file generated by the calculator can be used to generate water quality results with appropriate pollutant input and output EMCs. This approach was followed in this study to simulate TSS and TP reduction.

\subsection{Elm Drive Site Design}

Elm Drive is a mixed use street with residential homes on one side and an adult education centre on the other, as shown in Figure 1. The site consists of a treatment train of LID practices, consisting of permeable pavement and bioretention cells or planters, which filter and retain stormwater prior to discharge to Cooksville Creek and Lake Ontario.

The total area of the catchment is approximately $6456 \mathrm{~m}^{2}$. The permeable pavers cover $530 \mathrm{~m}^{2}$ of this area, while the bioretention cells make up $145 \mathrm{~m}^{2}$ of this area. The site drains $2578 \mathrm{~m}^{2}$ impervious area (road, directly connected roofs, sidewalk and driveway) and $3203 \mathrm{~m}^{2}$ pervious area, excluding areas of the LID features.

The permeable pavement lay-bys receive runoff from the street, while the permeable pavement sidewalk receives only the precipitation falling on its surface. Catchbasin sumps collect runoff from the lay-bys before it is conveyed to the bioretention cells via underground pipes. All bioretention cells are connected by an underdrain, which drains to the manhole downstream of the stormwater management system outlet. This is where the flow and water quality monitoring equipment is installed.

The permeable pavement has $700 \mathrm{~mm}$ depth of storage volume available in the setting bed aggregate. The lay-by and the sidewalk are sloped at $2.0 \%$ towards the catchbasin sump. A $200 \mathrm{~mm}$ pipe carries the collected stormwater from the sumps to each of the 6 bioretention cells. The bioretention cells consist of $450 \mathrm{~mm}$ thick engineered filter media layer, followed by $150 \mathrm{~mm}$ thick coarse concrete sand filter, followed by approximately $1000 \mathrm{~mm}$ thick high performance pipe bedding storage volume area. The $250 \mathrm{~mm}$ perforated storm pipe is located beneath the sand filter and entrenched in the storage area approximately $450 \mathrm{~mm}$ above the filter bed. It connects all the bioretention cells and outlets to the manhole downstream. The entire bioretention system is surrounded by nonwoven geotextile fabric. Further details on Elm Drive site and performance are available in the Elm Drive Technical Report (CVC 2015).

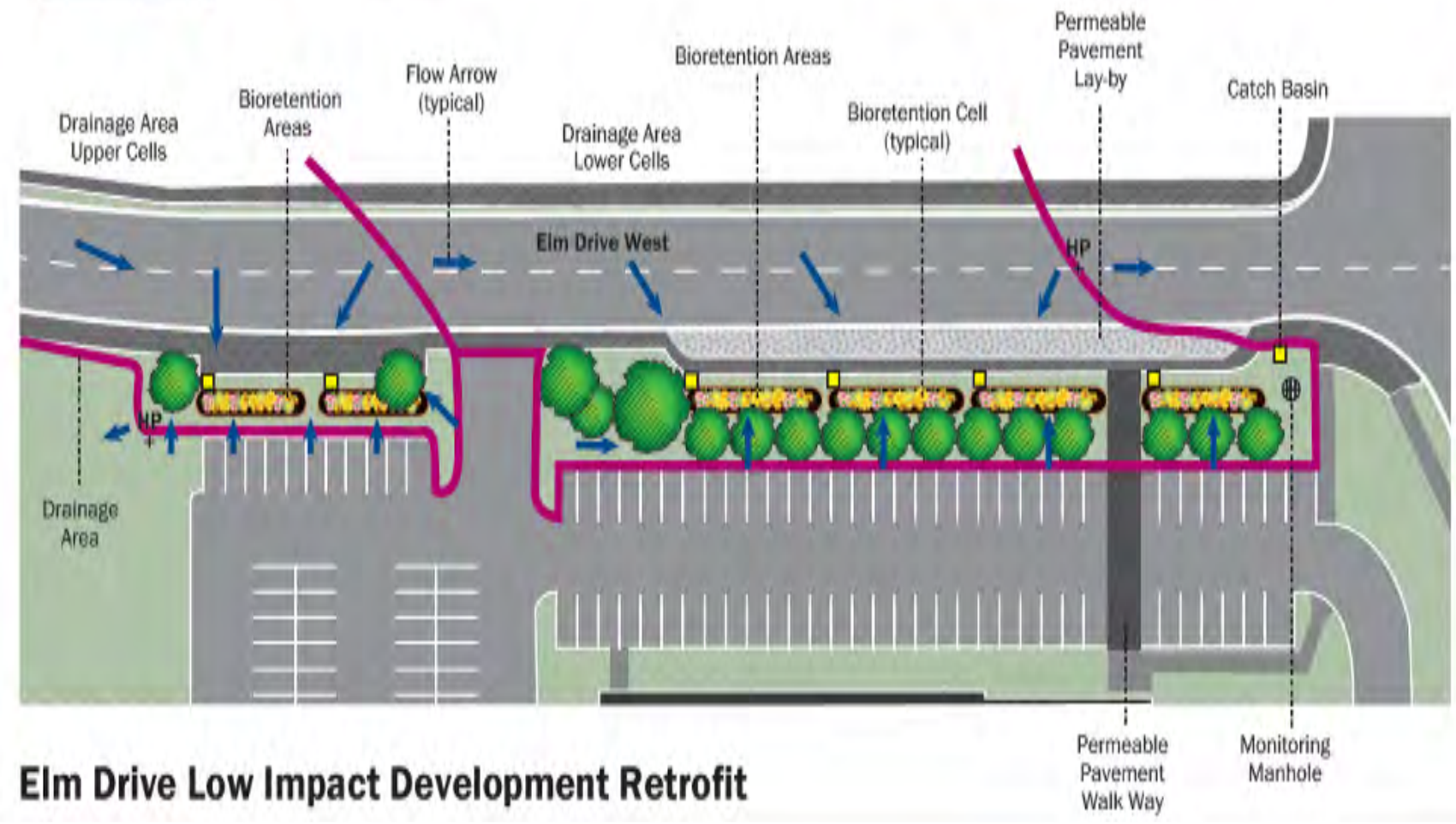

Figure 1 Elm Drive site plan. 


\subsection{Field Monitoring at Elm Drive}

The monitoring program at Elm Drive records a variety of information such as precipitation, outflow water quality and quantity, and inflow and outflow water temperature. Table 2 summarizes information about activities relevant to this study.

Table 2 Monitoring information for Elm Drive.

\begin{tabular}{|c|c|c|c|}
\hline Measurement type & Monitoring equipment & Location / description & Measurement \\
\hline Precipitation depth & Hydrological Services TB3 & Roof of Adult & Precipitation time series \\
\hline and intensity & Tipping Bucket Rain Gauge & Education Centre & Total $=757.4 \mathrm{~mm}$ \\
\hline \multirow[t]{5}{*}{ Flow (outflow) } & Custom Compound & \multicolumn{2}{|c|}{ Manhole downstream Water level time series in } \\
\hline & Weir by Thompson Flow & of bioretention & 10 min intervals \\
\hline & Investigations and ISCO & & \\
\hline & 4150 Flow Logger (water & & \\
\hline & level meter) & & \\
\hline Water quality & ISC0 6712 Automatic & \multirow{2}{*}{\multicolumn{2}{|c|}{$\begin{array}{l}\text { Manhole downstream Total suspended solids, } \\
\text { of bioretention total phosphorus }\end{array}$}} \\
\hline sampling (outflow) & Sampler & & \\
\hline
\end{tabular}

The site receives influent runoff as sheet flow and interflow (from permeable pavement sidewalks and lay-bys), which makes it difficult to measure influent. Influent then was not measured at Elm Drive but rather estimated using the Simple Method (Schueler 1987). The Simple Method transforms precipitation depth into runoff volume using the following equation:

$$
R=P^{*} P_{j}^{*} R_{v}
$$

where:

$$
\begin{aligned}
R= & \text { annual runoff (in.) } \\
P= & \text { annual rainfall (in.), } \\
P_{j}= & \text { fraction of annual rainfall events that produce } \\
& \text { runoff (usually } 0.9 \text { ), and } \\
R_{v}= & \text { runoff coefficient. }
\end{aligned}
$$

Runoff coefficient was based on a relationship developed by Schueler between impervious fraction and observed runoff. The impervious fraction was based on total impervious area versus total drainage area of the site:

$$
R_{v}=0.05+0.9 I_{a}
$$

where:

$$
I_{a}=\text { impervious fraction. }
$$

Effluent is measured downstream of the treatment train in a monitoring manhole. This setup uses a weir and a pressure transducer

\section{LID Modeling for Elm Drive}

The selected models and tools were set up using actual site design. Some of the parameters were calibrated because of the model or tool constraints, LID design guidelines, or sensitivity of a parameter. The important design guideline that was used to set up the models was I:P ratio (ratio of impervious portion of the drainage area to area of the receiving LID practice). For permeable pavement, I:P ratio of 2:1 was used for all the models and tools (CVC and TRCA 2010). The maximum I:P ratio of 15:1 was used for the bioretention cells. The sections below describe model and tool setup.

\subsection{Model Setup in MIDS Credit Calculator}

The precipitation data is hardwired in the MIDS code, which is assessed based on the site zip code. To use the tool for Elm Drive site, zip code 55069 was selected since precipitation at this location matched precipitation received at Elm Drive (see Figure 2).

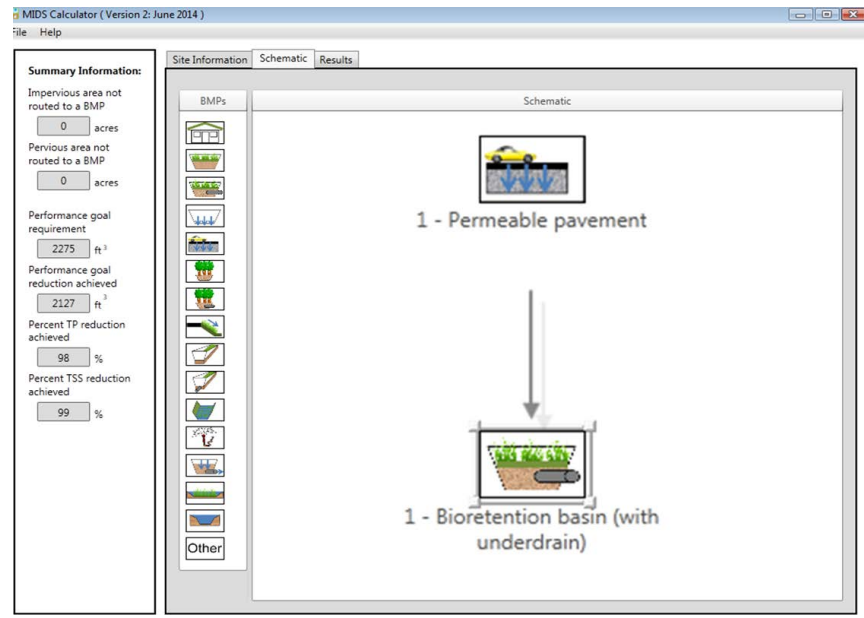

Figure 2 MIDS calculator interface depicting Elm Drive model setup.

Since MIDS accommodates treatment train design, this feature was used to setup the tool for Elm Drive. The impervious drainage area of the permeable pavement was restricted considering I:P ratio of 2:1. This implies that rest of the impervious area drained directly to the bioretention cells

The depth below underdrain of permeable pavement is $450 \mathrm{~mm}$. The native soil infiltration rate of the site is $10 \mathrm{~mm} / \mathrm{h}$ (0.4 in./h). This results in a drawdown time of $45 \mathrm{~h}$.

The bioretention planters have a total area of $145 \mathrm{~m}^{2}$. Parameters for the bioretention cells were acquired from the design drawings. The depth below underdrain for the bioretention cells is approximately $450 \mathrm{~mm}$, which meets the drawdown criteria.

For estimating water quality results, input concentration values of $87.5 \mathrm{mg} / \mathrm{L}$ for TSS and $0.3 \mathrm{mg} / \mathrm{L}$ for TP were used. These event mean concentrations were derived from the National Stormwater Quality database, using the median concentration for all samples collected under residential land use type in rain zone 1 areas only.

BMP pollutant removal efficiencies used for permeable pavement are $74 \%, 82 \%$ and $0 \%$ for TSS, PP and DP respectively. For bioretention the removal efficiencies used were $60 \%, 80 \%$ and $60 \%$ for for TSS, PP and DP respectively (MPCA 2014). 


\subsection{Model Setup in SWMM}

In SWMM, Horton's method was used to estimate infiltration. Monthly evaporation averages from Mora, Minnesota were used to estimate evaporation.

The site drainage area was modeled as 8 subcatchments, namely east and west residential areas, road areas, lawn areas, and bioretention areas (see Figure 3). Runoff is routed from residential area to road, and from road and lawn to the bioretention unit. Any excess runoff from west bioretention is routed to the east bioretention, which is the last discharge point for the site. Subcatchments were all given the same parameters: Manning's roughness value 0.012 for impervious area and 0.2 for pervious area; depression storage $1.27 \mathrm{~mm}$ for impervious area and $2.54 \mathrm{~mm}$ for pervious area.

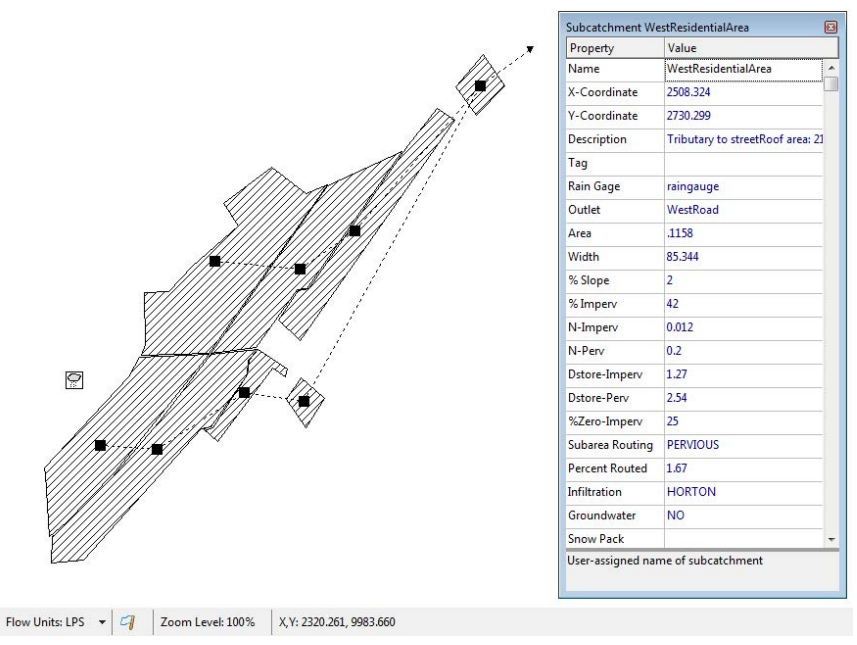

Figure 3 SWMM interface depicting Elm Drive model setup.

Residential subcatchments with roofs disconnected were sub-routed to pervious areas. West and east road subcatchments contained LID (permeable pavement) as part of the subcatchment, whereas bioretention was modeled as a separate subcatchment occupied fully by the LID control.

The depth below underdrain for permeable pavement had to be calibrated in SWMM to $50 \mathrm{~mm}$. This was done to force the model to mimic I:P ratio of 2:1.

For estimating water quality results, input EMC values of $87.5 \mathrm{mg} / \mathrm{L}$ for TSS and $0.3 \mathrm{mg} / \mathrm{L}$ for TP were used, as before. BMP pollutant removal efficiencies were defined in the Land Use editor. Different land uses were defined based on whether a catchment had a LID and the type of LID. Removal efficiencies used for permeable pavement are $75 \%$ for TSS and 56\% for TP. For bioretention removal efficiencies used were $75 \%$ for TSS and $60 \%$ for TP (CWP 2007 and MOECC 2012).

\subsection{Model Setup in SWC}

In order to use Elm Drive rain data, the SWMM input file generated by SWC was used in SWMM, with actual precipitation time series from the site. The SWC model (see Figure 4 below) was calibrated based on measured outflow. The parameters that were calibrated for the SWC model are presented in Table 3 below.

In SWC there is no provision to route from one LID to another, i.e. treatment train setup is not possible. Hence, $34 \%$ of the impervious area $\left(1060 \mathrm{~m}^{2}\right)$ is routed to permeable pavement, and the remaining to bioretention. Any excess runoff from permeable pavement becomes total outflow from the site. SWC has maximum limits for some LID design parameters like the depth of storage available. SWC does not have a water quality component either.

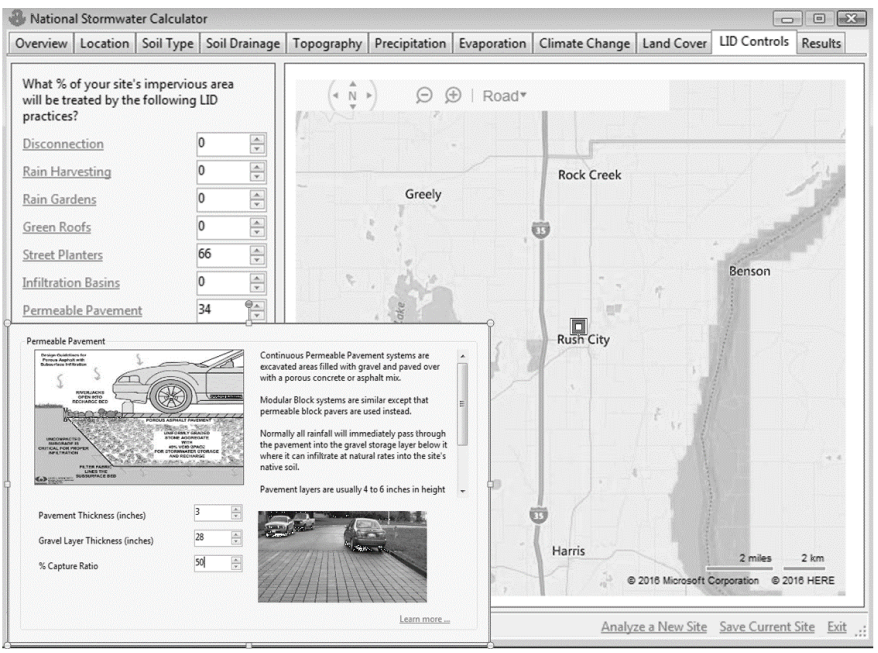

Figure 4 SWC interface depicting Elm Drive model setup.

Table 3 Calibration parameters for SWC model.

\begin{tabular}{lcc}
\hline & Design or Default value & Calibration \\
\hline Native soil hydraulic conductivity & $10.0 \mathrm{~mm} / \mathrm{h}$ & $5.75 \mathrm{~mm} / \mathrm{h}$ \\
Dstore-Perv & $5.0 \mathrm{~mm}$ & $2.54 \mathrm{~mm}$ \\
\%Zero-Imperv & 0 & 25 \\
Bioretention cell soil porosity & 0.45 & 0.25 \\
Bioretention soil suction head & $40.6 \mathrm{~mm}$ & $88.9 \mathrm{~mm}$ \\
Bioretention cell storage void ratio & 0.75 & 0.4 \\
Bioretention cell drain flow coefficient & 0 & $3.6 \mathrm{~mm} / \mathrm{h}$ \\
Permeable pavement drain flow coefficient & 0 & $3.6 \mathrm{~mm} / \mathrm{h}$ \\
Bioretention cell surface width & $12.0 \mathrm{~m}$ & $3.65 \mathrm{~m}$ \\
Permeable pavement surface width & 0 & $1.37 \mathrm{~m}$ \\
\hline
\end{tabular}

\subsection{Important Considerations}

An important consideration in modeling LID to get realistic results is that the impervious area draining to an LID should be capped. This is also based on recommendation made in the MIDS Manual (MPCA 2014), and LID SWM Planning and Design Guide (CVC and TRCA 2010). Impervious area routed should be $\leq 2$ times the area of the permeable pavement. Any runoff beyond this volume would bypass the system. Similarly, impervious area routed to bioretention should be 5 times to 15 times the area of the bioretention unit. 
The SWC does not have the capability to model treatment train (it lumps LID of the same kind together and cannot route from one system to another). However, since there is a maximum limit on impervious area treated by LIDs, the total impervious drainage area, which would actually be routed $100 \%$ to one LID and then routed to the second, can be divided between two or more LID facilities (e.g. $35 \%$ to one, $65 \%$ to the second) to represent the site.

In SWMM, when the second or final LID in a treatment train is part of a catchment which is $100 \%$ pervious or whose impervious area is less than the upstream catchment area to be routed to the LID, the LID must be modeled as a catchment on its own. If the LID is modeled as part of an existing catchment, the runoff routed to it will only be the precipitation falling on the LID plus runoff from the impervious area of the catchment it belongs to. The model will then not be modeling the actual inflow to the system but a reduced amount, thereby greatly underestimating LID performance.

SWMM has a LID routine with parameters specific to the LID type being modeled. Results are sensitive to the amount of infiltration modeled. Infiltration achieved by a LID depends upon the filter media, gravel layer and native soil properties such as infiltration rate, porosity and suction head, as well as depth of the filter media and storage layers, and depth of ponding available (Rossman 2010).

\section{Results and Discussion}

Results from the analysis are presented in Table 4. Precipitation and water level were monitored on the site for the year 2014. For a measured precipitation of $757.4 \mathrm{~mm}$ in 2014, a total outflow of $64.1 \mathrm{~mm}$ was observed (cumulative outflow from all rain, snow, and snow melt events). In other words, for an inflow volume of $2487 \mathrm{~m}^{3}$, the outflow is $414 \mathrm{~m}^{3}$. This amounts to an $83 \%$ volume reduction. Water quality sampling was also conducted and results indicate a total TSS load reduction of $93 \%$. Total TP load reduction is about $95 \%$.

Table 4 Monitored and modeling results for 2014.

\begin{tabular}{lcccc}
\hline & $\begin{array}{c}\text { Monitored } \\
\text { results }\end{array}$ & $\begin{array}{c}\text { MIDS Credit } \\
\text { Calculator }\end{array}$ & EPA-SWMM & $\begin{array}{c}\text { EPA Stormwater } \\
\text { Calculator }\end{array}$ \\
\hline Annual Precipitation (mm) & 757.4 & 757.0 & 757.4 & 757.4 \\
Inflow to LID treatment train (mm) & 385.3 & 382.3 & 367.3 & 302.5 \\
Outflow from LID treatmet train (mm) & 64.1 & 67.8 & 60.1 & 64.8 \\
Runoff reduction & $83 \%$ & $82 \%$ & $84 \%$ & $79 \%$ \\
Inflow TSS loading (g) & 217656 & 215910 & 210374 & $146888^{*}$ \\
Outflow TSS loading (g) & 14868 & 15422 & 26640 & $13000^{*}$ \\
TSS Load reduction & $93 \%$ & $93 \%$ & $87 \%$ & $91 \%$ \\
Inflow TP loading (g) & 746.0 & 739.4 & 721.0 & $503.5^{*}$ \\
Outflow TP loading (g) & 36.0 & 86.2 & 95.0 & $45.5^{*}$ \\
TP Load reduction & $95 \%$ & $88 \%$ & $87 \%$ & $91 \%$ \\
* Water quality results are not produced directly by the Stormwater Calculator. The SWMM input file generated by \\
the Calculator was run in EPA-SWMM to produce the water quality results included in this table.
\end{tabular}

The results reveal that all of the models are generally suitable for application at different design levels. MIDS Calculator and SWC are suitable for conceptual design only, while SWMM has more flexibility for entering several different LID practices and detailed design parameters for each practice. MIDS and SWMM could be configured for treatment train. SWC cannot directly mimic treatment train configuration; however, if the data is exported to SWMM, then the model could be adapted to LID practices in series.

Some of the models have maximum values on certain parameters to assist design, e.g. drawdown time in MIDS, soil media or storage depth in SWC. The study analysis also revealed that proper I:P is a key to proper LID design setup. The MIDS manual recommends a maximum I:P ratio of 5:1 for permeable pavement. Such criteria or guidance would be a valuable addition to all the models or user documents.

Media porosity or void ratio is normally not explicitly stated in LID design, so setting a default value or basing this value on other input is suggested. Recommended void ratio for storage layer is 0.4 (CVC and TRCA 2010).

Our analysis suggests that the models generate similar results for runoff volume reduction and pollutant load reduction when compared to monitored results. It is of significance to note that runoff reduction was not asymptotic when using MIDS and SWC. Caution should be taken in using the modeled results as such. These models are sensitive to underdrain depth. Therefore, a detailed model setup is important in the detailed design phase.

\section{Conclusions}

All three models are fairly suitable for setting up different LID practices and site conditions. Some models like MIDS and SWC assume default values for certain parameters and limit user entry; while SWMM allows complete user control for the entire model. Treatment train set-up is not possible in SWC. Neither is water quality modeling possible directly in SWC.

The modeled results for Elm Drive are similar to observed volume and pollutant load reduction results for all the models analysed. All models are sensitive to LID design details like depth of soil and storage layers and soil properties. Accuracy of the models is dependent on accuracy of input design parameters and refined through calibration and validation. Results suggest that MIDS and SWC could be used for conceptual design stage of a development, however, SWMM is recommended for the detailed design phase.

It was observed that the models have a high sensitivity to impervious area routed, depth of storage below underdrain, and native soil infiltration rate. Medium sensitivity is observed in SWMM5 to modeling LID as part of a subcatchment vs modeling LID as a separate subcatchment.

\section{References}

CVC. 2012. Stormwater Management Criteria. Mississauga, Ontario: Credit Valley Conservation. 
CVC and TRCA. 2010. Low Impact Development Stormwater Management Planning and Design Guide, Version 1.0. Mississauga, Ontario: Credit Valley Conservation, and Toronto and Region Conservation Authority.

CWP. 2007. National Pollutant Removal Performance Database, version 3. Ellicott City, MD: Center for Watershed Protection.

CVC. 2015. Elm Drive Low Impact Development Infrastructure Performance and Risk Assessment Technical Report. Mississauga, Ontario: Credit Valley Conservation Authority.

MOECC. 2003. Stormwater Management Planning and Design Manual. Toronto: Ministry of the Environment and Climate Change.

MOECC. 2012. Phosphorus Budget Tool in Support of Sustainable Development for the Lake Simcoe Watershed. Aurora, Ontario: Lake Simcoe Region Conservation Authority/Ministry of the Environment and Climate Change.
MPCA. 2014. Minnesota MIDS GUI Calculator User Manual Version 2. St. Paul, MN: Minnesota Pollution Control Agency.

Rossman, L. 2010. “Modeling Low Impact Development Alternatives with SWMM." Journal of Water Management Modeling R236-11. doi: 10.14796/JWMM.R236-11.

Schueler, T. 1987. Controlling Urban Runoff: A Practical Manual for Planning and Designing Urban BMPs. Washington, DC: Metropolitan Washington Council of Governments. 